\title{
Superstition as an economic institution: An evolutionary approach
}

\author{
Vladimir V. Maltsev \\ Financial University, Moscow, Russia, e-mail: vmaltsev92@gmail.com \\ Vyacheslav V. Dementyev \\ Financial University, Moscow, Russia, e-mail: dementyevv@mail.ru
}

Citation: Maltsev, V.V., Dementyev, V.V. (2021). Superstition as an economic institution: An evolutionary approach. Terra Economicus 19(2): 28-38. D0I: 10.18522/2073-6606-2021-19-2-28-38

The paper explores a hypothesis of evolution in superstitions. Using the framework of Peter Leeson on superstitions as productive socio-economic institutions and the historical case of the Orang Suku Laut (OSL) peoples of the Indonesian archipelago of Riau, we demonstrate that superstitions can adapt to the shifts in economic conditions surrounding them. The strained relations between the OSL and the Malays of Riau created a collective action problem: individual economic interaction between these groups was beneficial, but collectively the OSL risked getting subjugated by the Malays. To incentivize avoidance, the OSL utilized a system of belief called ilmu, and its superstition of lethal poisoning through trade. Ilmu prevented most intercommunity trade but allowed the OSL to retain their freedom. The siutaiton changed with the arrival of the Chinese middlemen to the archipelago, who introduced the institution of money to the OSL and caused them to become more progressive in the eyes of the Malays. This lessened the potential for conflict with the Malays and reduced the costs of trade. OSL then modified their superstition to render the exchanges safe if they were performed with money. As a result, the OSL superstition reached a new equilibrium which substantially improved the community's economic well-being. If our hypothesis is correct, then a spontaneous development of superstitions can enhance the material welfare in some socities, despite their objectively incorrect nature.

Keywords: anarchy; superstitions; evolution; Orang Suku Laut; ilmu; Indonesia; Malays; wealth maximization; game theory

Acknowledgements: We want to thank Natasha Purser for proofreading the paper, professor Peter Leeson for providing invaluable comments and feedback, and professor Cynthia Chou for elaborating on some details about the OSL in private correspondence.

JEL codes: B53, Z10, Z12, N35, N45

(C) В.В. Мальцев, В.В. Дементьев, 2021 


\title{
Суеверие как экономический институт: эволюционнъй подход
}

\author{
Владимир Владимирович Мальцев \\ Финансовый университет, Москва, Россия, e-mail: vmaltsev92@gmail.com \\ Вячеслав Валентинович Дементьев \\ Финансовый университет, Москва, Россия, e-mail: dementyevv@mail.ru
}

Цитирование: Maltsev, V.V., Dementyev, V.V. (2021). Superstition as an economic institution: An evolutionary approach. Terra Economicus 19(2): 28-38. DOI: 10.18522/2073-6606-2021-19-2-28-38

В статье исследуется гипотеза об эволюции суеверий. Используя труды Питера Лисона о суевериях как производительных социально-экономических институтах и исторический пример народа Оранг Суку Лаут (ОСЛ) с Индонезийского архипелага Риау, мы демонстрируем, что суеверия способны адаптироваться под изменяющиеся экономические условия. Враждебные отношения между осЛ и малайцами с Риау привели к проблеме коллективного действия: индивидуальное взаимодействие между группами было выгодным, но несло с собой существенные коллективные издержки в виде возможного подчинения ОСЛ малайцам. Для предотравщения взаимодействия между группами осЛ прибегли к религиозной системе илму, согласно которой человек может быть смертельно отравлен в процессе торговли. В результате, взаимодействие между группами было минимизировано и ОСЛ смогли сохранить свою свободу. Данная ситуация изменилась с прибытием китайских посредников на архипелаг, благодаря которым осЛ приняли институт денег и стали более прогрессивными в глазах малайцев. Это событие уменьшило вероятность конфликта и снизило издержки от торговли. Благодаря этому, ОСЛ модифицировали систему илму, в рамках которой торговля стала безопасной при условии использования в ней денег. В результате, система суеверий осл смогла достигнуть нового равновесия и значительно улучшить их экономическое благосостояние. Если наша гипотеза верна, то спонтанное развитие суеверий может укрепить материальное положение определенных обществ, несмотря на объективно ложный характер этого института.

Ключевые слова: анархия; суеверия; эволюция; Оранг Суку Лаут; илму; Индонезия; малайцы; максимизация богатства; теория игр

\section{Introduction}

Superstitions can be defined as a non-scientific, objectively false view of how the world functions. In the past decade, the research on superstitions has come to occupy a substantial niche within economics. The first notions of such research are encountered in Posner (1980), who states that "primitive superstitions appear to promote the economic well-being of the society". But the more detailed research on superstitions is contained in the articles of of Peter Leeson (2017: 47), who shows that rational utilization of superstitions can result in "socially productive" outcomes. Leeson explains that superstitious practices can fill important governance roles and result in socio-economic improvements in absence of better institutional solutions. Leeson also shows that many such superstitions exist in today's world; from using a lie detector to swearing an oath when becoming a president.

Superstitions arise as private means of providing or supporting self-governance to societies for which resorting to formal means of government is extremely costly. Such could happen if the government is corrupt, predatory or is simply absent, leaving individuals in a state of anarchy, where anarchy is understood as the absence of formal governance. Not every country has an effective system of courts, and not every government is willing to protect private property rights or supply its citizens 
with an efficient law code. Depending on particular historical and institutional circumstances, superstitions can help promote social cooperation through dispute resolution, protection of property rights and overcoming the problems of collective action. For instance, in their paper on sassywood poison trials in Liberia, Leeson and Coyne (2012) show that in absence of effective government courts, the common populace can instead rely on imbibing poisonous brews that can reveal a criminal. Leeson's (2013b) paper on vermin trials shows how superstition helped the Catholic Church in late medieval era to secure tithe collection when state enforcement was too costly. In each of these cases, through the use of rational choice framework, superstitions became important vehicles that supported self-governance. Of course, superstitions have their limitations. They can only work with a strong base of believers and may collapse under high skepticism. Nonetheless, skepticism can be overcome, for instance, through careful monitoring of group members to ensure that only strong believers comprise the group, as shown by Leeson (2013a) in his paper on gypsies.

However, a question remains in the studies of these superstitions, namely, about their potential for change. Many of the superstitions tackled by Leeson were effectively studied as a static snapshot of a particular time period in history. Very few of these superstitions have endured up to these days, and logic dictates that those superstitions that remain will be inevitably disposed of once the costs and benefits surrounding their use change in favor or state provision or other, more "scientific" means. Thus, a problem is formulated: can superstitions organically evolve ${ }^{1}$ to reflect the changes in economic conditions that surround them? And if so, how does that happen? So far, the question has remained completely unaddressed in the relevant literature, but it is necessary to discuss it, as it may have important implications towards the way that superstitions are treated.

Our paper seeks to fill this lacuna via a novel case study of the Orang Suku Laut (OSL) - a fringe group of Malay sea gypsies in Indonesia's Riau Archipelago. The OSL are known as sea people and boat dwellers, who live for months on their boats - sampans, and have adhered to such a lifestyle for centuries. A historically non-sedentiary existence ensured that the OSL were not properly integrated into the Indonesian state, essentially leaving them in a state of anarchy ${ }^{2}$ (Chou, 2004: 315).

A superstition called ilmu lies at the heart of the OSL's existence, which makes them a prime candidate for analysis through the theoretical framework of Leeson. The word "ilmu" is an Arabic-derived term which means "knowledge" and "science". It encompasses all forms of knowledge that include learning based on divine revelation, science, magic, any branch of knowledge or magic (Wilkinson, 1959: 421-422). The ilmu helps govern the relations between various OSL tribes and serves as an instrument of protecting the OSL property rights in their spells and artifacts. Furthermore, possessing ilmu for the OSL provides them with claims to their territories and essentially justifies their entire existence in Riau with an alternate path towards "Malayness".

And while through many centuries the OSL never experienced infighting, nonetheless they exist in an environment which is "fraught with unresolvable conflicts and contradictions" (Chou, 2005: 67). This characterization can be attributed largely due to the strained relations between the OSL and the greater Malays group in Riau, which constitutes the great majority of the population in the archipelago. The Malays consider the OSL as impure heretics, and pressure the sea gypsies into converting to Islam and fully integrating into the Indonesian state hierarchy. The costs of such development would be extremely high for the OSL, due to changes to their culture and subsequent insertion into a Malayan power structure dominated by blood ties and status based on these ties (Chou, 2004: 313-314). This situation creates a collective action problem for economic interaction. Individual OSL could benefit privately from trading or otherwise cooperating with the Malays. But with the strained relations between these two groups, there is a risk of any given trade interaction going wrong, which could potentially lead to a subjugation of the OSL by the Malays. Or, if the interaction does not lead to hostility, it can lead to passive pressure from the Malays towards the OSL to convert to their ways by deepening their connections. Subjugation would result in an exceedingly high cost for the OSL not only would they lose all the value of their spells and magical artifacts due to the ban on practice of bad ilmu in Malay society, but also renounce their ownership of the territories where they lived

\footnotetext{
The word "evolve" in this paper does not imply movement from something outdated or backward to something more progressive.

${ }^{2}$ Note again that we understand "anarchy" not as Hobbesian war of all against all, but merely an absence of state governance.
} 
for centuries. These costs would be borne by everyone in an OSL community and would far outweigh any individual benefits.

There exists no formal conflict regulation method between the OSL and the Malays, leaving them in a state of de facto anarchy vis-à-vis each other. The solution to this problem has to be devised privately. Sometimes, the OSL push back against the attempts at subjugation through methods of passive resistance, described by James C. Scott (2008). These methods often involve trickery, fake ignorance, and deception. For instance, the OSL may receive some benefits from the Malays in advance for promise of religious conversion, without following through on said promise (Lenhart, 2002). But overall, there are strong incentives for avoiding contact with the Malays altogether, and a particularly powerful means of such avoidance comes from the magical component of ilmu.

The superstitious component of ilmu consists of practice of black magic that, besides healing and fortune-telling uses, can be utilized to lethally poison others (Faucher, 2002: 160-161) ${ }^{3}$. The OSL believe that the property they possess is imbued with their soul, which can become poisoned or poison another party in exchange through that soul's malicious intent (Chou, 2005: 76). The Malays of Indonesia believe in ilmu too. The Malays themselves hold that good ilmu comes from Allah, while bad ilmu comes from spirits, such as the ones used by the OSL. Thus, the Malays' religious beliefs are a curious blend of Islam and ancient spiritual practices. But, more importantly, this shared view allows for a unique governance solution.

The fear of being lethally poisoned in trade has a governance benefit: it incentivizes avoidance of contact to prevent conflict between communities. However, this process comes at a cost. If one's property can get poisoned (or poison another party) in exchange by the new owner of the property (Chou, 2005: 76), then most of the intercommunity trade is prevented, since goods given or received from the members of another community may be vehicles of harmful magic. Thus, the fear of being poisoned through trade highly incentivizes the OSL to minimize economic relations with the Malays.

However, in the past few decades, the economic conditions surrounding the OSL have changed drastically. Riau experienced a great expansion of markets in the second half of the twentieth century due to the appearance of the Chinese middlemen, or thau-ke, as the OSL call them. Their presence not only opened up vast indirect exchange opportunities for the OSL, but more importantly for our analysis, brought down the costs of interaction between the OSL and the Malays. The Malays began to view those sea gypsies who relied on Chinese middlemen and their money as more "progressive" and thus were less inclined to subjugate them, viewing these OSL as a part of the greater Malay world. This greatly increased the benefits of trade by significantly bringing down the costs of interaction.

But how could the sea gypsies capture these economic gains with their poisonous superstition, which incentivizes avoidance? This paper presents a novel view that this outcome is possible, as long as the superstitions can be modified to meet the economic challenges that they face. Our hypothesis is simple: when a superstition-using society experiences a change in their structure of costs and benefits, their superstition can accommodate this new state of affairs to maximize wealth. The OSL in particular pointed out that the Chinese, the effective creators of the market, cannot poison via harmful magic. With that alteration, trade is safe to engage in, provided that the interactions are performed with via a magic-neutralizing intermediary: the Chinese middlemen and their institution of money.

The theory is built upon by referencing literature in the vein of rational choice theory of superstitions (Leeson, Coyne, 2012; Leeson, 2013a; 2013b). This research holds that even the most seemingly irrational institutions and practices that exist in societies, exist in them for a good reason (Leeson, 2017: 47). Another important contribution to our article comes from another paper by Leeson (2007), where subjugators begin to treat their potential victims as productive assets when provided with corresponding incentives. Something similar also occured between the OSL and the Malays after the arrival of the Chinese middlemen. We also utilize a renowned paper by Harold Demsetz (1967), drawing upon the analogy of replacing changes in property rights regimes with changes in supersti-

\footnotetext{
The dichotomy of "science" versus "non-scientific" (such as magic) is redundant in the Malay World, including the Orang Suku Laut communities. We do not wish to treat the system of ilmu from an ethnocentric perspective and imply that the members of the OSL are backward in their development. However, for the purpose of fitting the historical and anthropological studies of the OSL into the economics framework of studies of superstition, we must perform this delineation in relation to the poisonous aspect of ilmu, unfortunate as it may be.
} 
tions due to the introduction of extended markets. Research by Greif $(2006)$ and Landa $(1994 ; 2016)$ shows the role of middlemen in boosting trade networks and expanding markets. For the overview of the OSL and Malays, the we rely on the research efforts of scholars who perfomed field research on the OSL and Malays (Chou, 2004; 2005; 2016; Faucher, 2002; 2005; Lenhart, 2001; 2002).

The paper structure is as follows: part two provides a more detailed overview of the OSL, their system of beliefs, their relations with the Malays and outline the preconditions for a shift in the economic conditions for the sea gypsies. Part three aims to validate the novel claim that exogeneously introduced shifts in a given society's costs and benefits can cause a superstition to change in a wealth-maximizing direction and further reinforce it with empirical examples of trades between the OSL and the Malays after the arrival of the Chinese middlemen in Riau. Fourth part concludes.

\section{A brief overview of the Orang Suku Laut history}

The Orang Suku Laut inhabit "the northern and southern gateways to the Straits of Melaka and the southern tip of the Malay Peninsula extending all the way into Batam and the Riau Lingga archipelago of Indonesia"4 (Chou, 2016: 266). The OSL have traditionally lived on the sea, which endowed them with great understanding of marine culture and patterns, from the location of fish to knowledge of currents and tides.

Historical research (Andaya, 2010) shows that for many centuries, the OSL enjoyed a special relationship with the Malay sultan. They were indispensable to the ruling elite for fighting off external forces on the sea from the seventh to seventeenth centuries. For that they were granted possession of "the seas and what floated on them" through hereditary feudal right from the Sultan of Johor (Trocki, 1979: 56) alongside the privilege of becoming rakyat (subject) of the sultan. By the eighteenth century, as the Dutch presence grew in the region and Islamic faith spread through the country, the political power of the Sultanate began to wane and the influence of the OSL steadily diminished, until they became a fringe group in the Malay world. Thus, it can be said that the Orang Suku Laut's marginal status resulted through changes in political climate and social ideologies in the region.

Today the Orang Suku Laut are viewed negatively by the wider Malay society, and governancewise, the sea gypsies are left to themselves despite living on the territory of the Indonesian government. The Riau Archipelago is located on the political periphery of Indonesia, at a considerable distance from Jakarta and thus does not possess a high administrative status (Lenhart, 2002). The government appears to largely ignore the OSL altogether, as the administrative costs of governing over a low-population fringe society must be too high for the state apparatus vis-à-vis its benefits 5 .

The sea and its resources largely provide sustenance and the ability to engage in economic activity for the OSL, and their fishing voyages can last from a few days up to many months. In storm season, the OSL live along the coast in their constructed dwellings on wooden struts (Lenhart, 2001: 67). The overall economic activity of the OSL involves mostly catching fish but also diversifies into collecting sea cucumbers and chopping down mangrove trees for charcoal, as shown by Chou's (2010: 71) map of economic resources available to the sea gypsies.

Another important service that the OSL render is the provision of ilmu. This encompasses services from creating purely superstitious concoctions such as love potions or casting protective spells to providing useful medical skills, such as the delivery of babies. Magical artifacts in possession of the OSL, especially the ones that were passed through generations are also highly sought after. All these goods and services are in high demand in the region and thus, make trade with the OSL lucrative. Ilmu also protects the property rights of the OSL, allowing them to deepen their specialization in certain spells or mastery over magical artifacts. And, through ilmu, the OSL secure an alternate vision of "Malayness", which provides them with claims to their territories.

It is evident that due to geographical proximity, the prime demand for the OSL goods that services would come from the Malays. But, as mentioned earlier, there is great tension between the

\footnotetext{
${ }_{4}$ According to Chou (2005: 19), the OSL numbers from 1993 amount to 1757 males and 1652 females, which at that time constituted approximately 0.6 per cent of the total 565000 population in the Riau Archipelago. The Malays form the overwhelming majority of that population in the region.

The Riau Archipelago was brought under Indonesian administration as late as 1950.
} 
greater Malays and the OSL. The contemporary Malays consider the sea gypsies as unprogressive people, belonging on the very bottom of the social strata of the Malay world, due to their nomadic lifestyle and witchcraft practices (Faucher, 2005: 129), none of which is conducive to the Islamic faith and progressive statecraft.

The OSL face immense pressures from the Malays to convert to Islam, and subsequently, join the Indonesian state. According to Chou (2005: 46) "Those Orang Laut who refuse to be incorporated into this ordered world are seen as threatening, challenging, resisting, and endangering the ideal social structure." If the OSL and the Malays trade, they can benefit privately from such arrangements. But the exposure of the OSL to the Malays increases the pressures of conversion and the community as a whole is put under a risk of subjugation. If subjugated, the OSL would lose all the capital that they have accumulated in spells and artifacts and essentially renounce their claims on the land upon which they lived for countless centuries.

Let us model this situation. Assume that there are two individuals: one an OSL, and the other a Malay, who have two strategies available to them: trade and do not trade. Figure 1 depicts the results of their "dilemma":

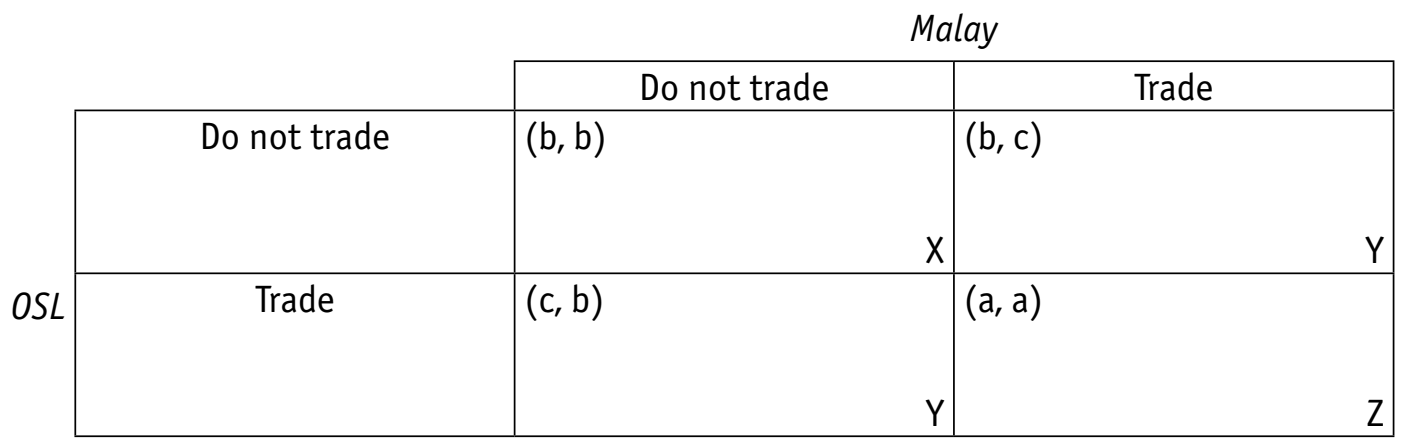

Fig. 1. The OSL and Malay trade dilemma

Source: compiled by the authors.

The private payoffs for the OSL and the Malay are shown in the upper-left corner, where $a>b>c$. The lower-right corner shows the payoffs to the OSL community, where $X>Y>Z$. If both parties engage in trade, both get their largest payoff $a$. However, the Orang Laut community as a whole gets its lowest benefit $Z$, due to the risk of exposure and subsequent subjugation. If OSL wants to trade, but the Malay does not, the OSL receives their lowest payoff $c$ as they incur the various costs of travel in their attempts to contact and negotiate the Malay. The OSL community gets a payoff $Y$ with a lesser risk of exposure and not establishing any connections to the Malays. The situation for the Malay and their community does not change, as they simply reject all attempts at trading and do not improve, not worsen their condition. The reverse situation yields corresponding payoffs as well, when the 0SL rejects attempts at trade by the Malay. Finally, if both parties do not trade, they both receive the payoff $b$, and the OSL community receives $X$ - its largest payoff for avoiding domination by a stronger group.

As such, the OSL are in a dilemma - there are definite gains from trade to be realized and private equilibrium is likely to be established at (trade, trade), but at the cost of great damage to the community. If foregoing trade results in greater net social benefits, the OSL communities are greatly incentivized to devise a method of avoidance. Here, the poisoning component of the ilmu superstition, which grants an individual the power to "possess the knowledge and ability to capture, subjugate, and harm the inner essence of others" comes into play (Chou 2005: 52). The OSL believe that a man's soul or its part can sometimes detach itself from the body of its owner. This soul or a part of it can then merge with another person or become embedded in a material object ${ }^{6}$, which allows to influence

\footnotetext{
It should be noted that this "embedding of the spirit" also doubles as the process of property claiming for the OSL. The OSL call the process of property claiming "adoption" and they believe that "by adopting a thing, a bond is established between the owner and the thing. This is so because the owner, by deciding to adopt a thing, is also making a decision to merge the thing with his or her own identity which, in essence, is the soul." This curious process somewhat resembles the Lockean principle of homesteading, where instead of labor, one's spirit essence mixes with a property object. For more information on the OSL's system of property see Chou (2005: 74-81).
} 
other people through witchcraft and even lethally poison them if the imparted spirits carry forth a malicious intent. This poisoning can occur not only through physical contact or proximity to one another, but also through trade. As Chou (2005: 59) writes, to receive an item through trade is to "accept (part of) the soul of the other". With this, let us alter the game from Figure 1 by introducing to it the poisoning aspect of ilmu superstition:

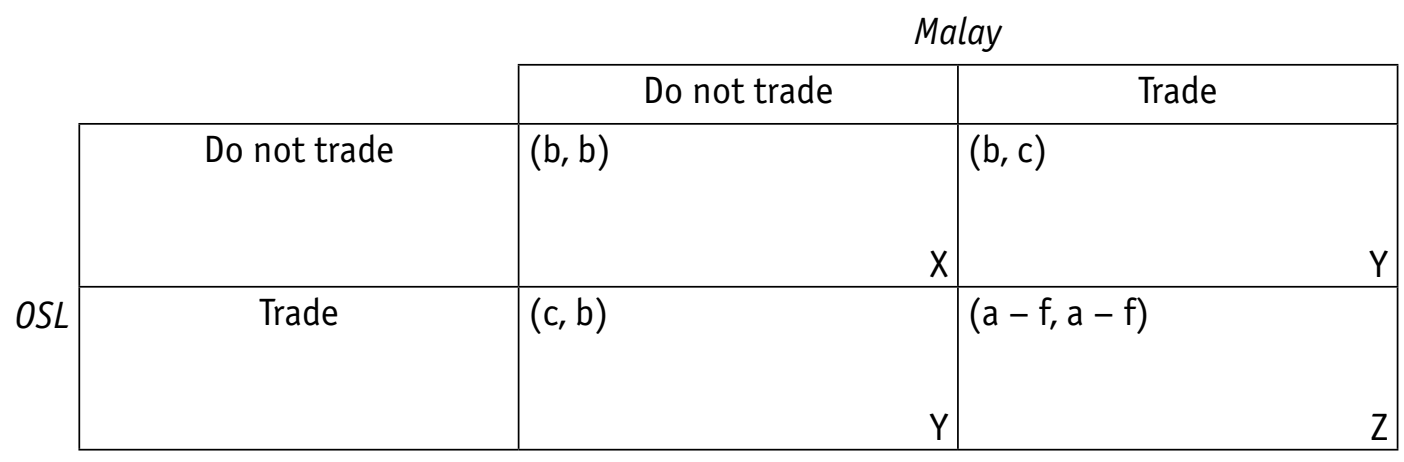

Source: compiled by the authors.

Fig. 2. The OSL and Malay trade dilemma with ilmu

Figure 2 shows that with ilmu poisoning he payoff from (trade, trade) strategies are transformed to $a-f$, where $f$ is a cost attributed to ilmu poisoning. If the fear of poisoning leads to a situation where $b>a-f$, then it will be beneficial for OSL and the Malay to shift to (do not trade, do not trade) equilibrium, and with it the OSL community will avoid subjugation, even if the individual payoffs will be much less as a result.

Of course, the superstition can only ensure such an outcome if both the Malays and the OSL believe in ilmu. It is evident that the OSL would not discard ilmu as the superstition provides them with a plethora of benefits. But then, why cannot the greater Malays simply deny ilmu and subjugate the OSL? First of all, as mentioned earlier, the ilmu is a large, complex system of belief and knowledge. To reject it is to reject knowledge itself. Secondly, the ilmu works to the benefit of the greater Malays too. Their position in social hierarchy depends directly on their purity of blood and unwavering adherence to the main tenets of Islam. The practice of OSL ilmu, on the other hand, serves as potent signal which allows the Malays to distinguish between someone from the upper social strata and the lower social strata like the sea gypsies. Without this signal, the Malays risk establishing an unwanted bond with the OSL and subsequently "lapsing to the lowest rung of the Malay hierarchy" (Chou 2005: 52). With the belief in ilmu secured by both groups, the equilibrium of $(a-f, a-f)$ held for some time.

This situation started to change with the arrival of the Chinese middlemen - thau-ke, to Riau. It is undeniable that middlemen in general increase the benefits of trade between communities by enabling indirect trade between them. Middlemen provide new trade opportunities, expand the networks between communities and beyond them, and substantially lower transaction costs. Contributions by Greif $(1989 ; 1993)$ for instance, document the organizing of a vast trade network in the Mediterranean by the Maghribi traders in the $11^{\text {th }}$ century. Landa $(1994 ; 2016)$ also shows that middlemen link consumers and producers in "complex networks of exchange" (Landa, 1994: 5), and that Chinese middlemen in particular tend to "dominate middlemen roles without special barriers to entry". The Chinese economic presence in Riau was no exception to the rule. The thau-ke have greatly expanded their presence in the Riau Archipelago in the last three decades of the $20^{\text {th }}$ century, facilitating trade in the region and outside it ${ }^{7}$. According to Chou (2005: 112), the Chinese set up

\footnotetext{
The process was not without complications. The Chinese population in Indonesia was highly discriminated against after the country achieved its independence. Presidential Decree No. 10/1959, for instance, banned rural trading by non-assimilated Chinese. Laws by President Suharto discouraged the use of Chinese language in public places while Chinese-character written literature was outright prohibited. However, these discriminatory laws were hard to enforce in the Riau Archipelago, due to its place on the political periphery of Indonesia, and its proximity to Singapore and Malaysia, which could have provoked an international scandal (Lyons, Ford, 2013: 123). Ananta et al. (2008: 33) further claims that the region's connections to Singapore and Malaysia and the eventual establishment of Badam Industrial Development Authority (BIDA) in 1971 ensured the region's status as an "economic magnet". As such, many Chinese relocated to Riau (Chou, Wee, 2002).
} 
new businesses and move goods across the disjointed OSL communities and provide the OSL with access to "extensive networks beyond the Malay World".

It is evident that the presence of middlemen increases the benefits of indirect trade for the OSL. However, the activities of the Chinese middlemen in Riau also caused the Orang Laut to experience an increase in direct trade between them and the Malays. Chou (2005: 122) writes that even with ilmu still retaining its poisonous nature, individuals in the Riau "deem it necessary to seek ilmu and other services from the other." How could that be possible if ilmu was utilized to encourage the avoidance of direct interaction between the sea gypsies and the Malays? For that event to transpire, the Chinese middlemen had to somehow bring down the hostilities between the OSL tribes and the Malays. By decreasing the pressures of subjugation, the value of $Z$ could drop significantly and in turn, increase the benefits of direct trade for the OSL. The Orang Laut could then modify their superstition to capture the gains from these shifts in economic conditions ${ }^{8}$. Let us see how that event transpired.

\section{A Wealth-maximizing Evolution of Superstitions}

The famous paper by Harold Demsetz (1967) "Toward a Theory of Property Rights" points towards a potential solution of the trade dilemma between the OSL and the Malays. In the article, Demsetz sets out to explain changes in property regimes, specifically the emergence of private property from common property. The Montagnes Indians had common property in forest land, inhabited by animals with prized furs. The property regime had a serious cost of "overhunting", but the costs of enforcing private property rights over the land were higher (Demsetz, 1967: 351-353). The emergence of a fur market in Europe exogenously increased the relative benefit of private property for the Indians. With the animals becoming more valueable as a resource, it became beneficial for the Montagnes to enforce private property rights over the lands they inhabited. In other words, the property system changed so as to "take account of the economic efforts made important by the fur trade" (Demsetz 1967: 352). It became wealth maximizing to "internalize the externality", so private property rights to the forest land emerged, changing the property regime.

Something largely similar was at work for the OSL, except the change occurred not with their property regime, but with the poison component of ilmu. This insight provides a crucial element to the entire discussion on superstitions, as it shows that superstitions can evolve in a wealth-maximizing way. It has already been previously established that the middlemen must have somehow influenced direct trade to warrant the changes in ilmu. How exactly did that transpire?

The Chinese influence in Riau became so dominant that it led to claims such as "A Chinese businessman's handwritten note in Chinese characters may carry as much weight as a government bank cheque anywhere in Riau" (Lyons \& Ford, 2013: 124). And by using the Chinese institution of money, the OSL could also tap into this trustworthiness. Indeed, the Malays began to "regard those Orang Laut who 'use money' as 'more progressive, modern, and clever' than those who 'still' practise barter only" (Chou 2005: 109). This echoes one of the conclusions reached by Leeson (2007: 315) in his paper "Trading with Bandits", where a weak group was able to minimize conflict with a more powerful group by transforming themselves through trade from being "targets of violence to productive assets". Similarly, by utilizing money, the OSL also became productive assets in the eyes of the Malays, which reduced the need for their immediate subjugation. Then, the social cost of trading for the OSL is reduced from $Z$ to $Y$.

As the costs of trade dropped and economic interaction became more and more beneficial, the ilmu evolved to capture these economic gains. The OSL proclaimed that the Chinese-introduced institution of money cannot serve as instrument of poisonous magic. Indeed, according to the 0SL, the Chinese themselves possess no ilmu, and the only Chinese that are capable of poisoning anyone are their physicians, due to their extensive knowledge. However, Chou (2005: 68) writes that "the Orang Laut are certain that Chinese physicians ... have no interest in poisoning anyone". Additionally,

\footnotetext{
Note that there is no option for these groups to dispose of ilmu. The Orang Suku Laut and Muslim Malays cannot discard ilmu as if they were to do so, this would mean that they would be discarding knowledge per se. And even if the OSL were to simply remove the poisoning element from it, it would have allowed an easy way for the Malays to subjugate the sea gypsies.
} 
money-based exchange, according to Chinese beliefs, divorces goods of the identity of their owners and as such "decreases the possibility of them being used as instruments for poisoning" (Chou, 2005: 117).

It is quite fascinating that the OSL have come to this realization, as it echoes the contributions of many renowned economists on the impersonal nature of markets and money. For instance, Milton Friedman (1981: 23) states that "the market is an impersonal mechanism that separates economic activities of individuals from their personal characteristics" and that it "enables people to co-operate in the economic realm regardless of any differences of opinion or views or attitudes they may have in other areas". Ludwig von Mises (1998: 310) also highlights the impersonal characteristics of the market economy with money, where economic agents "do not bother" with the personal characteristics of other market participants. Max Weber (1978: 636) did not shy away from calling the market economy "the most impersonal relationship of practical life into which humans can enter", and Hayek characterizes the world of money commerce as an impersonal "cash nexus" (2014: 130).

Economics as a discipline comes under frequent critique for its obsession with anonymity, and yet - this anonymity is precisely how the OSL justify a safe exchange with the Malays. By using money in trade, the OSL signal that they seek a de-personalized interaction and thus, no spiritual harm can come from the exchange. Since ilmu poisoning can only be aimed at a particular person, money negates that possibility, even in close proximity to others. Furthermore, during the exchange, the OSL sometimes utilize such items as trays, upon which money needs to be placed first and only then given to the other party, which further distances one party from another (Chou 2005: 125).

The use of money then removes the cost component $f$ from (trade, trade) equilibrium. As a result, the final game matrix that captures the most wealth-maximizing outcome is demonstrated in Figure 3:

\begin{tabular}{|c|l|l|l|}
\cline { 2 - 4 } \multicolumn{1}{c|}{} & \multicolumn{2}{c|}{ Dalay } \\
\hline Do not trade & $(\mathrm{b}, \mathrm{b})$ & $(\mathrm{b}, \mathrm{c})$ \\
& & $\mathrm{X}$ & \\
\cline { 2 - 4 } & & $(\mathrm{a}, \mathrm{a})$ & $\mathrm{Y}$ \\
\cline { 2 - 4 } & $(\mathrm{c}, \mathrm{b})$ & & \\
& & $\mathrm{Y}$ & \\
\hline
\end{tabular}

Fig. 3. Trade via Chinese middlemen and their institutions

Source: compiled by the authors.

In this case, the equilibrium is likely to be established at (trade; trade) as long as the trade is performed with the help of Chinese-introduced institution of money. This conclusion is further reinforced by providing empirical examples of the direct trades after the arrival of the Chinese to Riau. Chou describes an exchange between an OSL dukun (ilmu practitioner) Ceco and an unnamed Malay woman. Thinking that her son was bewitched and about to marry an OSL girl, which would have propelled the woman's family down the social hierarchy of the Malay world, the woman decided to contact a dukun for an antidote potion. Here, Chou describes the role of money in this deal, and how a potential conflict took a form of haggling and arguing for money. Even though the potion did not work in the end and the mother ended up just slapping her son back to his senses, what matters is the observation that the magical antidote was easily traded away without any complications or pressures ${ }^{9}$.

Finally, Chou describes the attempt of a Malay woman in obtaining magical artifacts from the 0SL, including an especially potent pounder that apparently possessed unrivalled healing properties. If these goods were obtained by the woman through a barter exchange, this would have led to a creation of "an undesirable ... tie", which would then allow for one's spirit essence to be corrupted through ilmu. To prevent this tie from being established, the Malay woman attempted to "sever" it via money to dissociate the spirit of the owner from these items. She was willing to

\footnotetext{
9 Money also allows the OSL to "commoditize" what would otherwise be an "inalienable" and thus, priceless possession.
} 
pay up to 50000 rupiah $^{10}$ in exchange for these artifacts. Ultimately, her offer was not enough to secure the deal (Chou, 2005: 80) ${ }^{11}$.

\section{Conclusion}

To conclude, this work has highlighted the previously unexplored hypothesis that superstitions can evolve to capture the changing economic structure of costs and benefits around them. We showed how the OSL's ilmu and its poisoning superstition resolved the collective action problems in their society vis-à-vis the Malays at the cost of trade. However, the superstition then changed with time to allow for direct trade when greater economic opportunities and relevant institutions were introduced to them with the arrival of the Chinese middlemen.

The result establishes a novel idea that superstitions need not be treated as locked-in and nondynamic institutional arrangements. As such, this can further enrich the discussion on non-objective views of the world and highlight the economic coordination they can introduce to any given system. Furthermore, the insight about the malleability of superstitions is important to shed the ethnocentric perspective on fringe, marginalized societies, and their beliefs. Institutions, including superstitions, exist in any given social strata for a reason. This precludes us from assuming that superstitious societies are hopelessly backward and must necessarily be inferior to more "scientific" and "rational" ones. This leads us to a paradoxical conclusion that by allowing superstitions to exist and develop, we may observe more societies that hold objectively false beliefs but can engage in productive economic activities that are no less efficient.

As we saw, closer examination reveals the ilmu as a potent rational tool, used in a plethora of situations, with conflict and trade management being but a mere fraction of its full institutional spectrum. This perspective may hint that there might not be a linear progression from "primitivity" towards a more complex state. And furthermore, it points us to a more detailed consideration of various institutional environments and their development from a bottom-up, decentralized approach as opposed to a top-down, centralized one, even at the risk of leaving some "objectively false" views intact. However, these "false" views may nevertheless prove themselves to be highly rational and socially productive.

Our contribution, if correct, also has potential policy implications. For instance, if the Indonesian government policymakers insist on fully integrating the sea gypsies into their state structure in the future, they must think very carefully about overriding the institutions existing in the OSL society, for there is a real risk of it resulting in a worse socio-economic outcome than observed currently.

\section{Jumepamypa / References}

Ananta A., Arifin E., Bakhtiar K. (2008). Chinese Indonesians in Indonesia and the province of Riau Archipelago: A demographic analysis. In: Suryadinata L. (ed.) Ethnic Chinese in Contemporary Indonesia. Institute of Southeast Asian Studies.

Andaya L.Y. (2010). Leaves of the Same Tree: Trade and Ethnicity in the Straits of Melaka. Singapore: NUS Press.

Chou C. (2004). The Orang Suku Laut: Owners of or strangers in the Riau Archipelago of Indonesia? pp. 309-328. In: Berland J.C., Rao A. (eds.) Customary Strangers: New Perspectives on Peripatetic Peoples in the Middle East, Africa, and Asia. Praeger.

Chou C. (2005). Indonesian Sea Nomads: Money, Magic and Fear of the Orang Suku Laut. Routledge. Chou C. (2010). The Orang Suku Laut of Riau, Indonesia: the inalienable gift of territory. NY: Routledge. Chou C. (2016). The water world of the Orang Suku Laut in Southeast Asia. TRaNS: Trans-Regional and-National Studies of Southeast Asia 4(2): 265-282.

\footnotetext{
${ }^{10} 50000$ rupiah are roughly equal to 35 USD (in 2019 dollars). At the time when average nominal monthly wages in the country were approximately 67789 rupiah, this sum can be considered substantial enough to engage in trade (see Chun, Khor, 2010: 10).

${ }^{11}$ It can also be stated that the exchange would not have been possible to perform in the first place, as the pounder can be categorized as an item that the OSL view as "inalienable" and thus impossible to buy or sell.
} 
Chou C., Wee V. (2002). Tribality and globalization: The Orang Suku Laut and the "growth triangle" in a contested environment, pp. 318-363. In: Benjamin G., Chou C. (eds.) Tribal communities in the Malay World. International Institute for Asian Studies and Institute of Southeast Asian Studies.

Chun N., Khor N. (2010). Minimum wages and changing wage inequality in Indonesia. Asian Development Bank Economics Working Paper Series, № 196.

Demsetz H. (1967). Toward a theory of property rights. American Economic Review 57(2): 347-359.

Faucher C. (2002). Magical discourse, moral boundaries, and the mapping of interrelations in the Riau Archipelago. Asian Journal of Social Science 30(1): 158-176.

Faucher C. (2005). Regional autonomy, Malayness and power hierarchy in the Riau Archipelago, pp. 125-140. In: Erb M., Sulistiyanto P., Faucher C. (eds.) Regionalism in Post-Suharto Indonesia. Routledge.

Friedman M. (1981). Capitalism and freedom. In: Raico R. (ed.) New Individualist Review. Indianapolis: Liberty Fund.

Greif A. (2006). Institutions and the Path to the Modern Economy: Lessons from Medieval Trade. Cambridge University Press.

Hayek F.A. (2014). The Road to Serfdom: Text and Documents: The Definitive Edition. Routledge.

Landa J. (1994). Trust, Ethnicity, and Identity. Ann Arbor: University of Michigan Press.

Landa J. (2016). Economic Success of Chinese Merchants in Southeast Asia: Identity, Ethnic Cooperation and Conflict. Springer.

Leeson P.T. (2007). Trading with Bandits. The Journal of Law and Economics 50(2): 303-321.

Leeson P.T. (2013a). Gypsy Law. Public Choice 155(3-4): 273-292.

Leeson P.T. (2017). Coase, Posner, and Austrian law and economics, pp. 46-62. In: Boettke P.J., Zywicki T.J. (eds.) Research Handbook on Austrian Law and Economics. Cheltenham: Edward Elgar Publishing.

Leeson P.T., Coyne C.J. (2012). Sassywood. Journal of Comparative Economics 40: 608-620.

Leeson, P.T. (2013b). Vermin Trials. The Journal of Law and Economics 56(3): 811-836.

Lenhart L. (2001). Orang Suku Laut communities at risk: Effects of modernisation on the resource base, livelihood and culture of the 'Sea Tribe People' of the Riau Islands (Indonesia). Nomadic Peoples 67-88.

Lenhart L. (2002). Orang Suku Laut identity: The construction of ethnic realities. In: Benjamin G., Chou C. (eds.) Tribal Communities in the Malay World: Historical, Cultural and Social Perspectives. Institute of Southeast Asian Studies.

Lyons L., Ford M. (2013). The Chinese of Karimun: Citizenship and belonging at Indonesia's margins, pp. 121-137. In: Siew-Min Sai, Chang-Yau Hoon (eds.) Chinese Indonesians Reassessed: History, Religion and Belonging. London and New York: Routledge.

Mises L. von (1998). Human Action: A Treatise on Economics. Scholar's Ed. Auburn, Ala.: Ludwig von Mises Institute.

Posner R. (1980). A Theory of Primitive Society, with Special Reference to Law. Journal of Law and Economics 23(1): 1-53.

Scott J.C. (2008). Weapons of the Weak: Everyday forms of Peasant Resistance. Yale University Press.

Trocki C.A. (1979). Prince of Pirates: The Temenggongs and the Development of Johore and Singapore, 1784-1885. Singapore: Singapore University Press.

Weber M. (1978). Economy and Society: An Outline of Interpretive Sociology. University of California Press. 